\title{
ANALISIS KEMAMPUAN REPRESENTASI MATEMATIS DALAM PEMECAHAN MASALAH GEOMETRI SERTA FAKTOR-FAKTOR YANG MEMPENGARUHINYA
}

\author{
Rezki Amaliyah AR ${ }^{\mathbf{1}}$, Nurfadilah Mahmud ${ }^{\mathbf{2}}$ \\ ${ }^{1,2}$ Universitas Sulawesi Barat, Jl. Baharuddin Lopa, SH, MH., Kab. Majene, Sulbar
}

\begin{abstract}
This is qualitative research with a descriptive-explorative approach that aims to determine students' mathematical representation skills in solving Geometry problems. The population is all students in the mathematics education department who study Basic Geometry. The main subject was chosen by stratified technique and purposive sampling. The instruments are placement tests, diagnostic tests, and guided interviews. Data collection uses a triangulation method that aims to examine legitimate data. The results showed that 1) subjects with high skills always present visual representations and mathematical expressions, 2) subjects with intermediate skills present visual representations and mathematical expressions, and verbal but less representative representations, 3) subjects with low skills don't present visual representations and mathematical expressions and verbal representations of problem-solving steps; and 4) there are several factors that influence the ability of mathematical representation to solve geometric problems, among others, subjects are less able to present problems in geometric patterns, because the subject does not understand the problem.
\end{abstract}

Keywords: Mathematics representation; problem-solving; Geometry

\section{PENDAHULUAN}

Keberhasilan akademik mahasiswa merupakan tujuan utama dalam proses pendidikan pada tingkat perguruan tinggi. Apalagi mahasiswa pada program studi Pendidikan Matematika, sebagai calon guru yang akan mentransfer ilmu pengetahuannya kepada peserta didiknya. Dalam mempelajari matematika, ruang lingkup materi yang dianggap sulit oleh peserta didik adalah materi geometri. Hal ini sejalan dengan Nur'aeni (2008) yang menyatakan bahwa geometri adalah cabang ilmu matematika yang paling sulit dimana membutuhkan pemahaman dan penalaran konsep yang baik. Tanpa adanya pemahaman konsep dan penalaran yang baik, seseorang akan mengalami kesulitan dalam belajar geometri. Oleh sebab itu, sebagai seorang calon guru, mahasiswa Program Studi Pendidikan Matematika sejak dini harus mempersiapkan diri agar mampu mengajarkan materi geometri dengan baik kepada peserta didiknya sehingga geometri tidak lagi menjadi momok yang menakutkan bagi peserta didik. 
Salah satu kemampuan yang mendukung agar siswa dapat menguasai geometri adalah kemampuan representasi dalam pemecahan masalah. Representasi matematis dan pemecahan masalah memiliki hubungan yang kuat. Montague mengatakan bahwa pada dasarnya pemecahan masalah mempunyai dua langkah, yaitu representasi masalah dan menyelesaikan masalah (Alhadad, 2010). Pemecahan masalah yang sukses tidak mungkin tanpa representasi masalah yang sesuai. Representasi masalah yang sesuai adalah dasar untuk memahami masalah dan membuat suatu rencana untuk memecahkan masalah. Siswa yang mempunyai kesulitan dalam merepresentasikan masalah Matematika akan memiliki kesulitan dalam melakukan pemecahan masalah.

Dalam belajar matematika, representasi merupakan dasar atau pondasi bagaimana seorang siswa dapat memahami dan menggunakan ide-ide matematika. Seperti yang dikemukakan oleh Hwang, Chen, Dung, dan Yang (2007), bahwa ketika menyelesaikan masalah aplikasi matematika, siswa perlu mengamati dan menemukan pola-pola khusus yang ada di dalam masalah tersebut. Yakni, siswa perlu untuk memformulasi masalah tersebut menjadi bentuk masalah matematika yang abstrak atau model matematika. Dalam proses memformulasi inilah, siswa harus mempunyai ketrampilan representasi ganda (multiple representation) untuk mengartikulasi masalah yang sama dalam bentuk atau pandangan yang berbeda (Dahlan \& Juandi, 2011)

Beberapa manfaat atau nilai tambah yang diperoleh pengajar atau peserta didik sebagai hasil pembelajaran yang melibatkan representasi matematis adalah sebagai berikut: 1) pembelajaran yang menekankan representasi akan menyediakan suatu konteks yang kaya untuk pembelajaran guru; 2) Meningkatkan pemahaman siswa; dan 3) meningkatkan kemampuan siswa dalam menghubungkan representasi matematis dengan koneksi sebagai alat pemecahan masalah. (Mudzakir, 2006)

Menurut Effendi (dalam Akasi, Marcell, \& Perdana, 2015), kemampuan representasi matematis diperlukan siswa untuk menemukan dan membuat suatu alat atau cara berpikir dalam mengkomunikasikan gagasan matematis dari yang sifatnya abstrak menuju konkret, sehingga lebih mudah untuk dipahami. Untuk menghubungkan ide ide tersebut, mereka dapat merepresentasikan ide tersebut melalui gambar, grafik, simbol, ataupun kata-kata sehingga menjadi lebih sederhana dan mudah dipahami.

Hwang, Chen, Dung, dan Yang (2007) menyatakan bahwa representasi dibedakan dari konteks. Terdapat representasi eksternal (real word) dan representasi internal 
(mind). Representasi internal didefinisikan sebagai proses berpikir tentang ide-ide matematik yang memungkinkan pikiran seseorang bekerja atas ide tersebut (Dahlan \& Juandi, 2011). Memahami konsep matematika yang lebih penting bukanlah penyimpanan pengalaman masa lalu, tetapi bagaimana mendapatkan kembali pengetahuan yang telah disimpan dalam ingatan dan relevan dengan kebutuhan, serta dapat digunakan ketika diperlukan. Proses mendapatkan pengetahuan yang relevan dan penggunaanya sangat terkait dengan pengkodean pengalaman masa lalu tersebut. Proses tersebut merupakan aktivitas mental, yang oleh karenanya disebut representasi internal (Goldin, 2002). Representasi internal tentu saja tidak dapat diamati secara kasat mata dan akibatnya tidak dapat dinilai karena apa yang ada di dalam pikiran (minds on) tidak diketahui. Namun demikian, perwujudan dari minds on tersebut akan terlihat dalam perkataan (lisan) atau tulisan dalam bentuk pernyataan, simbol, ekspresi, notasi matematika, gambar, grafik, dan dalam bentuk lainnya. Perwujudan tersebut dinamakan dengan representasi eksternal (Goldin, 2002). Jadi, dapat disimpulkan bahwa representasi internal dan representasi eksternal berhubungan satu sama lain dan saling mendukung.

Setiap siswa mempunyai cara yang berbeda untuk membangun pengetahuannya dalam memecahkan masalah matematika (terkhusus geometri) yang diberikan oleh guru. Sangat memungkinkan bagi siswa untuk mencoba berbagai macam representasi dalam memahami suatu konsep dan menyelesaikan masalah. Namun, keterbatasan seorang guru dalam merepresentasikan materi berpengaruh juga pada keterbatasan siswanya karena siswa cenderung untuk mengikuti apa yang diajarkan oleh guru. Melihat pernyataan ini, menjadi tantangan sebagai calon guru, mahasiswa Prodi Pendidikan Matematika harus mempersiapkan diri sejak dini tentang bagaimana cara mengatasi kesulitan peserta didik tersebut.

Sejalan dengan hal tersebut, perlu dideskripsikan lebih dalam bagaimana kemampuan representasi matematis dalam pemecahan masalah geometri mahasiswa program studi Pendidikan Matematika, sebagai calon guru yang nantinya akan mengajar materi geometri pada siswa. Serta, faktor apa saja yang mempengaruhi kemampuan representasi matematis dalam pemecahan masalah geometri mahasiswa Program Studi Pendidikan Matematika Universitas Sulawesi Barat. Penelitian ini sebagai langkah awal untuk menemukan solusi permasalahan yang terkait dengan kemampuan representasi 
matematis dan pemecahan masalah mahasiswa. Seperti yang dilakukan oleh beberapa peneliti (Akasi, Marcell, \& Perdana, 2015); (Rosyid, 2016); (Maesaroh, 2013); (Fauji, 2014); (Hamdalah, 2016) mencoba menyelesaikan masalah yang menyebabkan rendahnya kemampuan representasi siswa dengan cara menemukan, menerapkan berbagai strategi dan model pembelajaran yang mampu meningkatkan kemampuan representasi matematis siswa.

\section{METODE PENELITIAN}

Penelitian ini adalah penelitian kualitatif dengan pendekatan deskripsi-eksploratif yang memberikan gambaran mengenai situasi dan kondisi (fakta aktual) yang sebenarnya mengenai kemampuan representasi matematis dalam memecahkan masalah Geometri. Subjek dalam penelitian ini adalah Mahasiswa Program Studi Penididikan Matematika Semester II tahun 2018 FKIP Universitas Sulawesi Barat yang sedang memprogram mata kuliah Geometri Dasar. Pemilihan subjek utama menggunakan teknik pengambilan stratified sampling dan purposive sampling.

Instrumen utama dalam penelitian ini adalah "peneliti". Sedangkan instrumen pendukung dalam penelitian ini meliputi tes awal, tes diagnostik, dan pedoman wawancara. Pada tes awal, masalah yang diberikan merupakan kumpulan soal yang sudah dipelajari pada materi Geometri. Selanjutnya hasil tes dijadikan acuan untuk pemilihan subjek penelitian dan dilakukan pemilihan subjek terhadap mahasiswa yang memperoleh hasil tes dengan skor perolehan nilai yang dikategorikan tinggi, sedang dan rendah.

Tes diagnostik kemampuan representasi matematis dalam memecahkan masalah geometri yang digunakan dalam penelitian ini berupa tes tulis yang terdiri dari 3 soal/masalah uraian. Data dari tes tulis dianalisis berdasarkan indikator representasi matematis dari setiap tahapan-tahapan pemecahan masalah Polya sehingga dapat diketahui sejauh mana tingkat kemampuan representasi matematis mahasiswa di setiap tahapan Polya yaitu memahami masalah, menyusun strategi pemecahan masalah, melaksanakan strategi penyelesaian/menyelesaikan masalah, mengecek kembali hasil penyelesaian masalah. Tes yang dilakukan ini termasuk dalam jenis representasi eksternal. Data ini kemudian diperkuat dengan wawancara. Gambaran analisis kemampuan representasi matematis mahasiswa mengacu pada indikator aspek penilaian 
kemampuan representasi matematis siswa yang disusun oleh Mudzakir (2006), yaitu representasi visual (Vs) berupa diagram/grafik/ tabel, persamaan/ ekspresi matematis (EP) dan representasi verbal ( $\mathrm{Vb}$ ) berupa kata-kata/ teks tertulis. Masalah geometri yang diajukan dalam tes diagnostik disajikan pada Tabel 1.

Tabel 1. Masalah geometri pada tes diagnostik

\begin{tabular}{ll}
\hline Masalah (1) & $\begin{array}{l}\text { Garis } \mathrm{ABCD} \text { membentuk huruf } \mathrm{Z}(\mathrm{AB}=\mathrm{BC}=\mathrm{CD}, \mathrm{AB} / / \mathrm{CD}) \text {, garis } \mathrm{DE} / / \\
\mathrm{BC}(\mathrm{DE} \text { lebih pendek dan } \angle C D E \text { lancip). Hubungkan } \mathrm{A} \text { ke E memotong } \mathrm{BC} \\
\text { di F. Tentukan panjang } \mathrm{BF}, \text { jika panjang } \mathrm{AB} \text { dan DE diketahui ! }\end{array}$ \\
\hline Masalah (2) & $\begin{array}{l}\text { Buktikan jika pada } \triangle \mathrm{ABC} \text { dengan } \angle A \text { tumpul, dan } \overline{A D} \text { adalah proyeksi } \\
\overline{A C} \text { pada } \overline{A B} \text {, maka berlaku bahwa } \overline{B C}^{2}=\overline{A C}^{2}+\overline{A B}^{2}+2 \overline{A B} . \overline{A D} !\end{array}$ \\
\hline Masalah (3) & $\begin{array}{l}\text { Ruas garis yang menghubungkan titik tengah dari dua sisi suatu segitiga } \\
\text { sejajar dengan sisi ketiga, dan panjangnya sama dengan setengah panjang } \\
\text { sisi ketiga. Buktikan! }\end{array}$ \\
\hline
\end{tabular}

Dalam instrumen pedoman wawancara, pertanyaan-pertanyaan yang disusun didasarkan pada tujuan untuk mengetahui kemampuan representasi matematis mahasiswa dalam memecahkan masalah geometri berdasarkan langkah-langkah Polya dan untuk menggali informasi proses berpikir mahasiswa yang belum atau tidak tertuang dalam lembar jawaban menyelesaikan masalah geometri. Wawancara ini juga dilakukan untuk mengungkap secara kualitatif kemampuan mahasiswa dalam pemecahan masalah dan faktor-faktor apa saja yang menyebabkan mahasiswa kesulitan dalam merepresentasikan ide-ide matematisnya. Wawancara ini termasuk dalam jenis representasi internal.

Secara garis besar tahapan atau prosedur penelitian ini dapat diuraikan sebagai berikut:

1. Merancang dan memvalidasi instrumen pendukung penelitian yang meliputi tes awal, tes diagnostik, dan pedoman wawancara.

2. Penentuan subjek penelitian

3. Pengumpulan data, meliputi a) memberikan lembar tes awal kepada mahasiswa Program Studi Pendidikan Matematika untuk dijadikan acuan dalam menentukan subjek penelitian dengan memilih subjek dengan interval nilai yang dikategorikan tinggi, sedang, dan rendah, b) memberikan tes diagnostik kemampauan representasi matematis, dan c) mewawancarai subjek yang terpilih terkait tes diagnostik yang telah diberikan 
4. Analisis data, meliputi a) analisis hasil tes awal secara kuantitatif, b) analisis data hasil tes diagnostik secara kualitatif, c) menganalisis hasil wawancara, d) triangulasi data, e) reduksi, coding, dan penyajian data

5. Menyusun pelaksanaan eksplorasi (pembahasan hasil analisis) kemampuan representasi matematis mahasiswa dalam memecahkan masalah geometri Program Studi Pendidikan Matematika Universitas Sulawesi Barat.

6. Verifikasi, dan penarikan kesimpulan

7. Analisis hal-hal yang menarik, yakni analisis perilaku yang ditunjukkan subjek penelitian yang tidak terencana dan tidak terkait dengan tujuan penelitian.

\section{HASIL DAN PEMBAHASAN}

Hasil analisis tes awal kemampuan pemecahan masalah 54 mahasiswa Program Studi Pendidikan Matematika disajikan dalam Tabel 2 berikut ini.

Tabel 2. Distribusi Frekuenasi Skor Tes Awal Kemampuan Pemecahan Masalah

\begin{tabular}{ccccc}
\hline No. & Skor & Frekuensi & Persentase (\%) & Kategori \\
\hline 1 & $0-49$ & 10 & 18.52 & Rendah \\
2 & $50-75$ & 35 & 64.81 & Sedang \\
3 & $76-100$ & 9 & 16.67 & Tinggi \\
\hline & Total & $\mathbf{5 4}$ & $\mathbf{1 0 0 \%}$ & \\
\hline
\end{tabular}

Dari Tabel 2 terlihat bahwa dari 54 mahasiswa yang mengikuti tes awal kemampuan pemecahan masalah geometri, 9 mahasiswa (16,67\%) memiliki kemampuan pemecahan masalah yang tinggi, 35 mahasiswa $(64,81 \%)$ memiliki kemampuan pemecahan masalah yang sedang, dan 10 mahasiswa $(18,52 \%)$ memiliki kemampuan pemecahan masalah yang rendah. Hasil ini menunjukkan bahwa kemampuan pemecahan masalah geometri mahasiswa Program Studi Pendidikan Matematika mayoritas berada pada kategori kemampuan sedang. Selanjutnya data tes awal ini digunakan untuk memilih subjek utama penelitian menggunakan stratified sampling, yaitu mengambil dua orang subjek dari masing-masing kategori. Serta berdasarkan purposed sampling yaitu memilih subjek yang mampu berkomunikasi dengan baik berdasarkan hasil pengamatan dosen dalam kelas geometri.

\section{Deskripsi Kemampuan Representasi Matematis}

Pengumpulan dan analisis data representasi matematis dilakukan dengan metode triangulasi dari hasil tes diagnostik dan wawancara pada 2 orang subjek yang identik atau cenderung sama kemampuan representasi matematisnya sehingga mendapatkan 
data yang jenuh dan dianggap valid mewakili setiap kategori kemampuan pemecahan masalah pada tes awal yaitu tinggi, sedang, dan rendah. Adapun deskripsi hasil analisis kemampuan representasi matematis dalam pemecahan masalah geometri sebagai berikut:

Tabel 3. Hasil Kemampuan Representasi Matematis Pemecahan Masalah

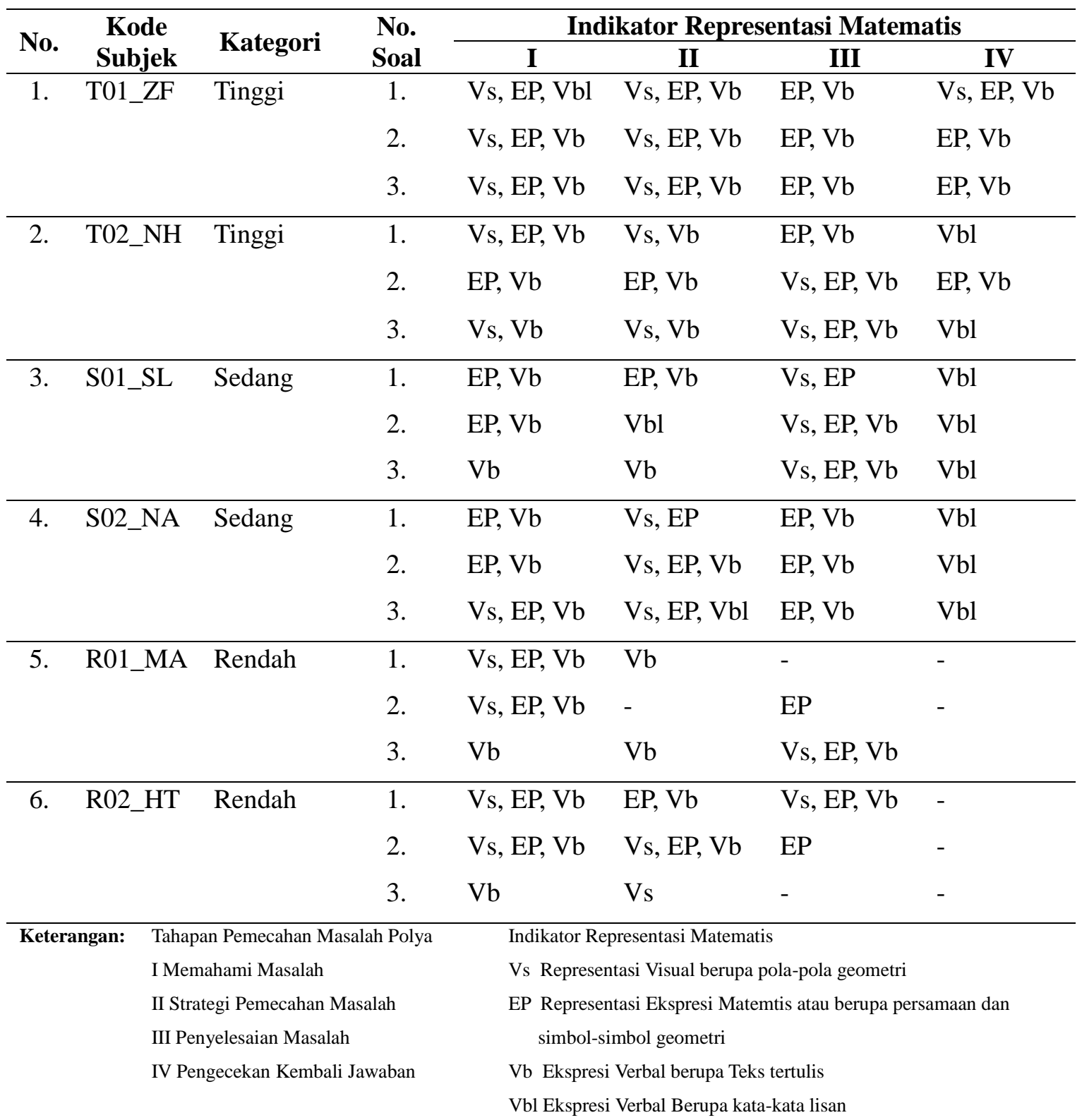

1) Deskripsi Kemampuan Representasi Matematis pada Subjek Kategori Tinggi

Berdasarkan Tabel 3, tahap memahami masalah dan merencanakan strategi penyelesaian masalah 1 , subjek menggunakan representasi visual berupa gambar geometri, simbol/ekspresi geometri dan menggunakan representasi verbal. Pada tahap penyelesaian masalah, subjek menggunakan simbol geometri/ekspresi 
matematis dan teks/kata-kata. Sedangkan pada tahap pengecekan kembali, subjek menggunakan representasi visual berupa gambar geometri, ekspresi matematis dan representasi verbal secara lisan maupun tulisan. Selanjutnya, pada pemecahan masalah 2, dalam memahami dan merencanakan strategi penyelesaian masalah, subjek menggunakan representasi ganda (multi representasi) berupa gambar geometri, simbol geometri, dan menggunakan representasi verbal. Pada tahap penyelesaian masalah 2, subjek menggunakan simbol geometri/ekspresi matematis dan teks/kata-kata. Sedangkan pada tahap pengecekan kembali, subjek menggunakan representasi ekspresi matematis dan representasi verbal secara lisan. Sama halnya pada pemecahan masalah 1 dan 2, dalam memecahkan masalah 3, subjek juga menggunakan representasi ganda pada tahap memahami masalah dan merencanakan strategi penyelesaian masalah berupa pola geometri, simbol geometri, dan menggunakan representasi teks. Sedangkan pada tahap penyelesaian masalah, subjek menggunakan simbol geometri/ekspresi matematis dan teks/kata-kata. Pada tahap pengecekan kembali, subjek menggunakan representasi ekspresi matematis dan representasi verbal secara tulisan dan lisan. Secara lebih rinci representasi matematis subjek berkemampuan tinggi dapat dilihat pada hasil tes diagnostik yang disajikan pada Tabel 4 berikut.

Tabel 4. Representasi Matematis Subjek Kemampuan Tinggi

Masalah


Berdasarkan hasil analisis tersebut secara keseluruhan dapat dikatakan bahwa subjek dengan kemampuan pemecahan masalah pada kategori tinggi, mampu menyelesaikan masalah geometri dengan bantuan berbagai representasi matematis seperti representasi visual berupa pola-pola geometri, representasi ekspresi matematis berupa simbol-simbol geometri seperti titik, garis, garis sejajar, garis sama panjang, sudut, sudut yang sama besar, kesebangunan dan segitiga, serta representasi verbal berupa teks yang menjelaskan tahapan penyelesaian masalah. Jadi, untuk subjek berkemampuan tinggi memiliki kecenderungan penggunaan berbagai representasi matematis pada setiap tahapan pemecahan masalah geometri sehingga mampu menyelesaikan masalah dengan baik dan benar. Dalam memecahkan masalah matematika, khusunya geometri, dibutuhkan kemampuan representasi matematis yang menjadi alat yang berguna untuk memahami konsepkonsep geometri dan menggunakan representasi untuk menyelesaikan tugas dan untuk menjelaskan kepada orang lain (Panaoura, 2011).

\section{2) Deskripsi Kemampuan Representasi Matematis pada Subjek Kategori Sedang}

Berdasarkan Tabel 3, pada tahap memahami masalah 1, subjek hanya menggunakan ekspresi matematis dan sedikit representasi verbal. Sedangkan pada tahap merencanakan strategi penyelesaian masalah 1 dan penyelasaian masalah 1 , subjek menggunakan representasi visual berupa gambar geometri, simbol geometri, dan menggunakan representasi verbal. Pada tahap pengecekan kembali, subjek tidak menuliskan apapun pada tes diagnostik, tapi secara verbal mampu menjelaskan caranya saat wawancara. Selanjutnya, pada pemecahan masalah 2, pada tahap memahami masalah, subjek menggunakan ekspresi matematis dan teks verbal dan tahap merencanakan strategi penyelesaian masalah dan penyelesaian masalah, subjek juga menggunakan representasi ganda berupa gambar geometri, simbol geometri, dan menggunakan representasi verbal. Pada tahap pengecekan kembali, subjek tidak menuliskan apapun pada tes diagnostik, tapi secara verbal mampu menjelaskan caranya saat wawancara. Sedangkan pada pemecahan masalah 3, subjek juga menggunakan representasi ganda. Pada tahap memahami masalah dan merencanakan strategi penyelesaian masalah subjek hanya menggunakan satu atau dua jenis representasi. Selanjutnya pada tahap penyelesaian masalah, subjek menggunakan pola geometri, simbol geometri/ekspresi matematis dan teks/kata- 
kata. Pada tahap pengecekan kembali, lagi-lagi subjek tidak menuliskan apapun pada tes diagnostik, tapi secara verbal mampu menjelaskan caranya saat wawancara. Secara lebih rinci representasi matematis subjek berkemampuan sedang dapat dilihat pada Tabel 5.

Tabel 4. Representasi Matematis Subjek Kemampuan Sedang

\begin{tabular}{|c|c|c|}
\hline Masalah & Jawaban Soal & Keterangan \\
\hline 1 & $A, 6 \quad B$ & $\begin{array}{l}\text { Subjek menggunakan representasi visual } \\
\text { berupa pola geometri dan simbol-simbol } \\
\text { geometri seperti garis yang sama panjang, } \\
\text { namun kurang sesuai dengan syarat } \\
\text { masalah yang diajukan (sudut CDE Lancip) }\end{array}$ \\
\hline 2 & & $\begin{array}{l}\text { Subjek menggunakan representasi visual } \\
\text { berupa gambar geometri yang dimanipulasi } \\
\text { berdasarkan masalah, namun tidak } \\
\text { memberikan simbol garis yang tegak lurus }\end{array}$ \\
\hline 3 & 3 & $\begin{array}{l}\text { Subjek menggunakan representasi visual } \\
\text { berupa pola geometri dan simbol-simbol } \\
\text { geometri seperti garis yang sama panjang } \\
\text { secara tepat sesuai dengan masalah yang } \\
\text { diajukan, serta mencoba melakukan } \\
\text { manipulasi gambar untuk membantu } \\
\text { menyelesaiakan masalah (garis putus- } \\
\text { putus) }\end{array}$ \\
\hline
\end{tabular}

Berdasarkan hasil analisis tersebut secara keseluruhan dapat dikatakan bahwa subjek dengan kemampuan pemecahan masalah pada kategori sedang, menyelesaikan masalah geometri dengan bantuan berbagai representasi matematis namun kurang representatif seperti representasi visual berupa pola-pola geometri, representasi ekspresi matematis berupa simbol-simbol geometri seperti titik, garis, garis sama panjang, kesebangunan, dan segitiga, serta representasi verbal berupa teks yang menjelaskan tahapan penyelesaian masalah. Seharusnya ada simbol/ekspresi geometri seperti sudut untuk membantu penyelesaian masalah. Namun, terlupakan oleh subjek sehingga masalah 1 dan 3 tidak terselesaikan dengan tuntas. Meskipun subjek menggunakan representasi ganda, tidak menjamin kebenaran jawaban penyelasaian masalah apalagi jika pemilihan representasi yang kurang tepat atau tidak sesuai dengan masalah. Oleh sebab itu, representasi matematis haruslah beragam (multiple representation) dan menggunakan pola-pola 
yang tepat sesuai dengan masalah seperti yang diungkapkan oleh Hwang, Chen, Dung, dan Yang (2007), bahwa ketika menyelesaikan masalah aplikasi matematika, siswa perlu mengamati dan menemukan pola-pola khusus yang ada di dalam masalah tersebut. Yakni, siswa perlu untuk memformulasi masalah tersebut menjadi bentuk masalah matematika yang abstrak atau model matematika. Dalam proses memformulasi inilah, siswa harus mempunyai ketrampilan representasi ganda (multiple representation) untuk mengartikulasi masalah yang sama dalam bentuk atau pandangan yang berbeda (Dahlan \& Juandi, 2011).

3) Deskripsi Kemampuan Representasi Matematis pada Subjek Kategori Rendah

Dalam menjelaskan masalah 1, subjek menggunakan representasi visual berupa gambar geometri, simbol geometri, dan menggunakan representasi verbal pada tahap memahami masalah. Pada tahap merencanakan strategi penyelesaian masalah, subjek hanya menggunakan teks. Meskipun rencana strategi telah dituliskan, subjek tidak mampu menyelesaikan masalah. Pada masalah 2, tahap memahami masalah, subjek juga menggunakan representasi ganda berupa gambar geometri, simbol geometri, dan menggunakan representasi verbal. Tahap merencanakan strategi penyelesaian masalah, subjek hanya menggunakan teks. Sedangkan pada tahap penyelesaian masalah, subjek tidak mampu menyelesaikan masalah. Pada masalah 3, subjek hanya menggunakan representasi teks pada tahap memahami masalah dan merencanakan strategi penyelesaian masalah. Selanjutnya, pada tahap penyelesaian masalah, subjek menggunakan pola geometri yang kurang representatif sehingga tidak mempu menyelesaikan masalah dengan baik. Secara lebih rinci kemampuan representasi matematis subjek berkemampuan rendah pada hasil tes diagnostik disajikan pada Tabel 6 berikut:

Tabel 4. Representasi Matematis Subjek Kemampuan Rendah

\begin{tabular}{ll} 
Masalah & \multicolumn{1}{c}{ Keterangan } \\
\hline 1 & $\begin{array}{l}\text { Subjek menggunakan representasi visual } \\
\text { berupa pola geometri, namun kurang sesuai } \\
\text { dengan syarat masalah yang diajukan } \\
\text { (sudut CDE harusnya Lancip) }\end{array}$ \\
& $\begin{array}{l}\text { Subjek menggunakan representasi visual } \\
\text { berupa gambar geometri, namun tidak } \\
\text { sesuai dengan masalah seperti sudut A } \\
\text { harusnya tumpul }\end{array}$
\end{tabular}




\begin{tabular}{cl}
\hline Masalah & Jawaban Soal \\
\hline 3 & $\begin{array}{l}\text { Keterangan } \\
\text { berupa pola geometri. Namun kurang tepat } \\
\text { tidak sesuai dengan konsep geometri dan } \\
\text { masalah yang diajukan }\end{array}$ \\
\hline
\end{tabular}

Berdasarkan hasil analisis tersebut secara keseluruhan dapat dikatakan bahwa kemampuan representasi matematis dalam pemecahan masalah geometri untuk kategori berkemampuan rendah, kurang memiliki kemampuan penggunaan berbagai representasi matematis dalam pemecahan masalah pada tiap tahapan pemecahan masalahnya seperti representasi visual berupa pola-pola geometri, representasi ekspresi matematis berupa simbol-simbol geometri hanya sebatas titik dan garis, serta representasi verbal berupa teks yang menjelaskan tahapan penyelesaian masalah. Dikarenakan tidak mampu membuat representasi masalah dalam bentuk pola-pola geometri yang tepat sehingga masalah 1, 2, dan 3 tidak terselesaikan dengan benar.

\section{Faktor-Faktor yang Mempengaruhi Kemampuan Representasi Matematis}

Dari hasil tes diagnostik dan wawancara, beberapa faktor yang mempengaruhi kemampuan representasi matematis mahasiswa Program Studi Pendidikan Matematika dalam pemecahan masalah geometri sebagai berikut:

1. Kurangnya dasar-dasar pemahaman dan pengetahuan terkait konteks materi geometri. Seperti pada masalah III, subjek R01_MA membuat pola geometri yang salah karena tidak memahami defenisi sudut tumpul yang terdapat pada soal.

2. Subjek kurang mampu menyajikan masalah dalam pola-pola geometri, dikarenakan subjek kurang memahami masalah. Seperti pada masalah III, subjek R02_HT, tidak mampu menyelesaikan masalah karena tidak memahami masalah. Walaupun terlihat menggambar pola geometri, tetapi pola tersebut salah karena tidak sesuai masalah.

3. Subjek menggunakan representasi matematis yang kurang tepat. Seperti pada masalah 1, subjek S01_SL menggunakan representasi ganda dalam membantunya menyusun strategi pemecahan masalah, tetapi penyelesaian masalah tidak tuntas karena menggunakan representasi matematis yang tidak tepat, yaitu menyalahi syarat pada soal sehingga jawaban akhir pemecahan masalah yang dilakukan salah.

4. Subjek tidak mampu memanipulasi pola-pola geometri untuk membantu dalam penyelesaian masalah. Seperti pada masalah 1, subjek R02_HT hanya menyajikan 
pola geometri berdasarkan masalah, tapi tidak memanipulasi sedikitpun untuk membantunya dalam menyelesaikan masalah seperti tambahan ekspresi geometri lainnya (sudut, garis yang sama panjang, ataupun sudut)

5. Subjek merasa tidak memiliki keahlian dalam menggambar, sehingga gambar cenderung kurang representatif. Seperti pada hasil wawancara, rata-rata subjek memiliki masalah kurang mampu menggambar dengan baik dan benar tanpa menggunakan alat bantu kertas berpetak atau penggaris, sehingga garis yang seharusnya sama panjang terlihat tidak sama panjang.

6. Subjek cenderung memiliki kemampuan representasi internal dari pada representasi eksternal, karena kesulitan menuangkan apa yang dipahami dalam bentuk tulisan. Dari beberapa subjek, representasi verbal berupa teks tidak tertulis dalam lembar jawaban tes diagnostik, tapi pada proses wawancara, subjek mampu menjelaskan tahapan demi tahapan proses penyelesaian masalah dengan fasih.

\section{SIMPULAN DAN SARAN}

Mahasiswa Program Studi Pendidikan Matematika FKIP Universitas Sulawesi Barat memiliki rata-rata kemampuan pemecahan masalah geometri kategori sedang sebesar $64,81 \%$. Hal ini dipengaruhi oleh kemampuan representasi matematis dalam pemecahan masalah yang masih kurang, subjek dalam pemecahan masalah geometri menyajikan representasi visual berupa pola-pola geometri namun kurang representatif, menggunakan ekspresi matematis yang tidak beragam dan kurang representasi secara verbal. Namun, penggunaan representasi kurang tepat. Meskipun menggunakan representasi ganda, kemampuan pemecahan masalah geometri mahasiswa kategori tinggi sebesar 16,67\%, dimana kecenderungan kemampuan representasi matematis subjek dalam memecahkan setiap masalah geometri selalu menyajikan representasi visual, ekspresi matematis berupa simbol yang sesuai dan beragam, dan menggunakan representasi verbal pada tiap tahapan pemecahan masalah. Sebaliknya, kategori rendah sebesar $18,52 \%$, dimana subjek dalam pemecahan masalah geometri tidak menyajikan representasi visual yang tepat, sedikit menggunakan ekspresi matematis dan cenderung hanya menggunakan representasi verbal sehingga satupun masalah yang diajukan tidak memiliki penyelesaian yang benar. Adapun faktor-faktor yang mempengaruhi kemampuan representasi matematis mahasiswa diantaranya: a) kurangnya dasar-dasar 
pemahaman dan pengetahuan terkait konteks materi geometri; b) kurang mampu menyajikan masalah dalam pola-pola geometri; c) menggunakan representasi matematis yang kurang tepat; d) tidak mampu memanipulasi pola-pola geometri untuk membantu dalam penyelesaian masalah; e) tidak memiliki keahlian dalam menggambar, sehingga gambar cenderung kurang representatif; dan f) cenderung memiliki kemampuan representasi internal dari pada representasi eksternal, karena kesulitan menuangkan apa yang dipahami dalam bentuk tulisan.

Mengajarkan geometri kepada peserta didik bukanlah hal mudah. Sebagai calon guru matematika, mahasiswa Program Studi Pendidikan Matematika FKIP harus memiliki keterampilan menggunakan representasi ganda matematis yang tepat dalam pemecahan masalah geometri mengingat antara pemecahan masalah dan representasi matematis dua hal yang tak terpisahkan dan saling melengkapi satu sama lain. Calon guru harus memiliki keterampilan mengembangkan strategi pembelajaran geometri yang tepat dengan memperhatikan kemampuan representasi matematis peserta didik.

\section{DAFTAR RUJUKAN}

Akasi, A., Marcell, \& Perdana, M. I. (2015). Penerapan Model Pembelajaran Number Head Together (NHT) Terhadap Kemampuan Representasi Matematis. Edumatica Volume 05 Nomor 02, ISSN: 2088-2157, 48-54.

Alhadad, S. F. (2010). Meningkatkan Kemampuan Representasi Multipel Matematis, Pemecahan Masalah Matematis dan Self Esteem SiswaSMP melalui Pembelajaran dengan Pendekatan Open Ended. Disertasi Tidak Diterbitkan. Bandung: UPI Bandung.

Dahlan, J. A., \& Juandi, D. (2011). Analisis Representasi Matematis Siswa Sekolah Dasar dalam Pemecahan Masalah Matematika. Jurnal Pengajaran MIPA, Volume 16, Nomor 1, 128-138.

Fauji, T. (2014). Pengaruh Model Pembelajaran Kooperatif Tipe Think Pair Share (TPS) Terhadap Peningkatan Kemampuan Representasi Matematis Siswa. Skripsi Tidak Dipublikasikan. Bandar Lampung: Universitas Lampung.

Goldin, G. A. (2002). Perspective on Representation in Mathematical Learning and Problem Solving. Handbook of International Research in Mathematics Education (Second Ed.). , 176 -201.

Hamdalah, M. A. (2016). Penerapan Pembelajaran Berbasis Masalah untuk Meningkatkan Kemampuan Representasi Matematis dan Self Confidence Siswa. Skripsi Tidak Dipublikasikan. Bandar Lampung: Universitas Lampung. 
Hwang, W. Y., Chen, N. S., Dung, J. J., \& Yang, Y. L. (2007). Multiple representation skills and creativity effects on mathematical problem solving using a multimedia whiteboard system. Educational Technology \& Society, 10(2), 191-212.

Maesaroh, E. (2013). Peningkatan Kemampuan Representasi dan Komunikasi Matematik melalui Pembelajaran Kooperatif Student Teams Achievement Divisions (STAD) berbantuan Program CABRI siswa SMA. Tesis Tidak Dipublikasikan. Bandung: Pascasarjana Universitas Pasundan Bandung.

Mudzakir, H. S. (2006). Strategi Pembelajaran Think-Talk-Write untuk Meningkatkan Kemampuan Representasi Matematik Beragam Siswa SMP. Disertasi Tidak Dipublikasikan. Bandung: UPI (Tersedia Online): http://repository.upi.edu.

Nur'aeni, E. (2008). Teori Van hiele Dan Komunikasi Matematik (Apa, Mengapa, dan Bagaimana). In prosiding seminar nasional matematika dan pendidikan matematika. Jurusan Pendidikan Matematika Fakultas Matematika dan Ilmu Pengetahuan Alam Universitas Negeri Yogyakarta.

Panaoura, A. (2011). Young Students' Self - Beliefs Abou Using Representations in Relation to The Geometri understandings. Nicosia, Cyprus: Frederick University

Rosyid, A. (2016). Pemanfaatan Software CABRI Geometri dengan Pendekatan Induktif terhadap Peningkatan Kemampuan Representasi Matematis Siswa SMP. Jurnal Matematika Ilmiah STKIP Muhammadiyah Kuningan Vol. 2 No.1 , 70-84. 